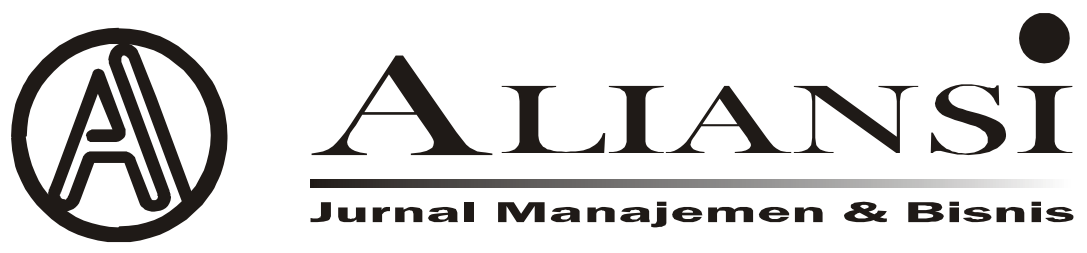

\title{
PREDIKSI KEBANGKRUTAN TAKSI KONVENSIONAL YANG TERDAFTAR DI BEI
}

\author{
Oleh : Fardiman', Melati Ambar Tanjung ${ }^{2}$, Inung Wijayanti ${ }^{3}$ \\ email : Fardiman@perbanas.id ${ }^{1}$, inung@perbanas.id ${ }^{3}$
}

\begin{abstract}
The purpose of this study was to determine the prediction of corporate bankruptcy. In this study, the companies studied were conventional taxi transportation listed on the IDX for the 2016-2019 period. These companies include PT Blue Bird Tbk. And PT Express Transindo Utama Tbk. For company research, researchers used 4 methods, namely Altman Modification, Springate, Grover, and Zmijewski methods. This type of research is descriptive quantitative. The data source used is secondary data. The population in this study are transportation companies listed on the BEI as many as 8 companies. The research sample used purposive sampling method, with a sample of 2 conventional taxi service companies. The results of this study indicate that there are differences in the calculation results from the use of 4 bankruptcy prediction methods, where PT Blue Bird Tbk has always been in the non-bankruptcy criteria except in 2019 with the Springate method in the bankruptcy criteria, while PT Express Transindo Utama Tbk. always on the criteria for bankruptcy except in 2016 with the Altman Z-Score Modification method which was in the gray area criteria and in 2016 with the Grover method it was in the non-bankruptcy criteria. Among the 4 bankruptcy prediction methods used to predict conventional taxi services, the highest accuracy is the Zmijewski method with an accuracy rate of 100\%." “Keywords: Altman Modification, Springate, Grover, Zmijewski
\end{abstract}

\section{PENDAHULUAN}

Seiring dengan meningkatnya kegiatan ekonomi dan aktvitas masyarakat menyebabkan keperluan jasa transportasi semakin meningkat. Meskipun keperluan jasa transportasi semakin meningkat, tetapi saat ini sektor transportasi memiliki tingkat persaingan yang sangat tinggi, karena munculnya beberapa perusahaan jasa transportasi berbasis online yang berkembang dengan pesat seperti Gojek dan Grab. Munculnya perusahaan jasa transportasi berbasis online sangat bermanfaat bagi masyarakat. Di samping tarifnya yang sangat murah, masyarakat semakin dimudahkan dengan adanya transportasi berbasis online, yaitu dengan hanya memesan melalui aplikasi, driver akan menjemput di titik penjemputan dan akan mengantar di titik pengantaran.

Salah satu driver transportasi taksi konvensional PT Express Transindo Utama Tbk. mengungkapkan sejak beroperasinya transportasi online, penghasilannya menurun. Dengan menurunnya penghasilan yang didapat oleh driver, Perusahaan akhirnya menurunkan setoran wajibnya. Menurunnya setoran wajib berdampak pada pendapatan yg dihasilkan oleh PT Express Transindo Utama Tbk., hal ini dibuktikan pendapatan perusahaan dalam tiga tahun terakhir ini terus menurun. Menurunnya pendapatan perusahaan jasa transportasi taksi konvensional disebabkan karena kalah bersaing dengan perusahaan jasa transportasi berbasis online terutama soal tarif. Dengan menurunnya pendapatan perusahaan jasa transportasi taksi konvensional, dikhawatirkan perusahaan jasa transportasi taksi konvensional mengalami kebangkrutan.

Menurut UU No. 37 Tahun 2004, perusahaan dinyatakan pailit berdasarkan pada keputusan pengadilan yang berwenang atau berdasarkan permohonan sendiri jika memiliki dua atau lebih kreditur dan perusahaan tidak mampu membayar sedikitnya satu kewajibannya yang telah jatuh tempo (Nugroho, 2018). Agar dapat mengantisipasi kebangkrutan perusahaan, manajemen perusahaan perlu melakukan analisis prediksi kebangkrutan untuk menilai kinerja keuangan perusahaan, dan untuk menentukan langkah yang akan diambil untuk mengatasi kondisi keuangan tersebut. Ada beberapa metode analisis kebangkrutan yang sering digunakan oleh perusahaan antara lain metode Altman Modifikasi, Springate, Grover, dan Zmijewski, yang menggunakan berbagai rasio dalam suatu persamaan diskriminan. Setiap metode menghasilkan hasil yang 
berbeda-beda sehingga diperlukan metode prediksi kebangkrutan perusahaan yang paling akurat. Tujuan penelitian ini adalah untuk dapat menganalisis apakah perusahaan jasa transportasi taksi konvensional berpotensi mengalami kebangkrutan dengan metode Altman Modifikasi, Springate, Grover, dan Zmijewski periode 2016 - 2019, dan mengetahui metode manakah yang paling akurat untuk digunakan.

\section{TINJAUAN TEORI}

\section{Kebangkrutan}

Menurut Suryana (2019), kesulitan keuangan atau biasa disebut kebangkrutan adalah situasi dimana arus kas dari aktivitas operasi perusahaan tidak cukup untuk memenuhi kewajiban lancar dan perusahaan terpaksa mengambil tindakan untuk memperbaikinya. Kebangkrutan adalah kegagalan perusahaan dalam mengelola keuangannya.

\section{Metode Altman Modifikasi}

Menurut Altman (1995) dalam Presetyo, Noor, dan Amiruddin (2018), formula persamaan dari metode Altman Modifikasi yaitu:

Z-Score $=6,56\left(X_{1}\right)+3,26\left(X_{2}\right)+6,72\left(X_{3}\right)+1,05\left(X_{4}\right)$

Keterangan:

Z-Score $=$ bankruptcy index

$\mathrm{X}_{1}=$ working capital / total asset

$\mathrm{X}_{2}=$ retained earning / total asset

$\mathrm{X}_{3}=$ earning before interest and tax / total asset

$\mathrm{X}_{4}=$ book value of equity / book value of total debt

Adapun kriteria penilaian yang digunakan dalam metode Altman Modifikasi adalah jika Z-Score < 1,1 termasuk dalam kriteria perusahaan bangkrut, jika $1,1<\mathrm{Z}$-Score $<2,6$ termasuk dalam kriteria perusahaan grey area (daerah abu-abu), jika ZScore $>2,6$ termasuk dalam kriteria perusahaan tidak bangkrut.

\section{Metode Springate}

Menurut Yuliastary dan Wirakusuma (2014) dalam Pertapan, Hartono, dan Wulan (2018), formula persamaan dari metode Springate yaitu:

S-Score $=1,03(\mathrm{~A})+3,07(\mathrm{~B})+0,66(\mathrm{C})+0,4(\mathrm{D})$

Keterangan:

S-Score $=$ bankruptcy index

$\mathrm{A}=$ working capital / total asset

$\mathrm{B}=$ earning before interest and tax / total asset

$\mathrm{C}=$ earning before tax / current liabilities

$\mathrm{D}=$ sales / total asset
Adapun kriteria penilaian yang digunakan dalam metode Springate adalah jika skor S-Score < 0,862 termasuk dalam kriteria perusahaan bangkrut, dan jika S-Score > 0,862 termasuk dalam kriteria perusahaan tidak bangkrut.

\section{Metode Grover}

Menurut Prihanthini dan Sari (2013) dalam Effendi (2018), formula persamaan dari metode Grover yaitu: G-Score $=1,650\left(\mathrm{X}_{1}\right)+3,404\left(\mathrm{X}_{2}\right)+0,016(\mathrm{ROA})+0,057$ Keterangan:

G-Score = bankruptcy index

$\mathrm{X}_{1}=$ working capital / total asset

$\mathrm{X}_{2}=$ earning before interest and tax / total asset $\mathrm{ROA}=$ net income / total asset

Adapun kriteria penilaian yang digunakan dalam metode Grover adalah jika G-Score $<-0,02$ termasuk dalam kriteria perusahaan bangkrut, dan jika G-Score $>0,01$ termasuk dalam kriteria perusahaan tidak bangkrut.

\section{Metode Zmijewski}

Menurut Effendi (2018), formula persamaan dari metode Zmijewski yaitu:

$\mathrm{X}$-Score $=-4,3-4,5\left(\mathrm{X}_{1}\right)+5,7\left(\mathrm{X}_{2}\right)+0,004\left(\mathrm{X}_{3}\right)$

Keterangan:

$\mathrm{X}$-Score $=$ bankruptcy index

$\mathrm{X}_{1}=$ net income / total asset

$\mathrm{X}_{2}=$ total liabilities / total asset

$\mathrm{X}_{3}=$ current asset / current liabilities

Adapun kriteria penilaian yang digunakan dalam metode Zmijewski adalah jika X-Score > 0 ( nol ) termasuk dalam kriteria perusahaan bangkrut, dan jika X-Score < 0 ( nol ) termasuk dalam kriteria perusahaan tidak bangkrut.

\section{Penelitian Terdahulu}

Penelitian yang dilakukan oleh Effendi (2018) menyimpulkan bahwa berdasarkan hasil analisis PT Express Transindo Utama Tbk. Menggunakan metode Springate pada tahun 2012 - 2016 berada dalam kriteria bangkrut. Menggunakan metode Zmijewski pada tahun 2012 - 2015 berada dalam kriteria tidak bangkrut, dan tahun 2016 berada dalam kriteria bangkrut. Menggunakan metode Grover pada tahun 2012 - 2016 berada dalam kriteria tidak bangkrut. Penelitian yang dilakukan oleh Prasetyo, dkk. (2018), menyimpulkan bahwa berdasarkan hasil analisis PT Express Transindo Utama Tbk. pada tahun 2012 - 2016 dengan menggunakan metode Altman Z-Score berada pada kriteria grey area, dan pada tahun 2017 berada pada kriteria bangkrut. 
Penelitian yang dilakukan oleh Pertapan, dkk. (2018) menyimpulkan bahwa berdasarkan hasil analisis PT Blue Bird Tbk pada tahun 2011 sampai 2013 dengan menggunakan metode Altman Z-Score berada dalam kriteria bangkrut, pada tahun 2014 berada dalam kriteria grey area, dan pada tahun 2015 sampai 2016 berada dalam kriteria safe area. Menggunakan metode Springate S-Score berada pada kriteria safe area. Menggunakan metode Zmijewski $\mathrm{X}$-Score berada pada kriteria safe area.

\section{METEDEOLOGI PENELITIAN}

\section{Populasi dan Teknik Sampel}

Pada penelitian ini dilakukan analisis deskriptif kuantitatif. Populasi penelitian ini adalah 8 perusahaan subsektor transportasi darat yang terdaftar di Bursa Efek Indonesia (BEI) periode 2016 - 2019. Teknik sampel yang dilakukan dalam penelitian ini adalah purposive sampling yaitu dengan sengaja melakukan pengambilan sampel atas suatu kriteria tertentu. Kriteria pengambilan sampel adalah perusahaan subsektor transportasi darat yang bergerak dibidang jasa transportasi taksi konvensional berjumlah 2 perusahaan yaitu PT Blue Bird Tbk. (BIRD) dan PT Express Transindo Utama Tbk. (TAXI).

\section{Jenis dan Sumber Data}

Jenis data yang digunakan adalah data sekunder. Sumber data yang digunakan berupa laporan keuangan publikasi periode 2016-2019 yang didapat dari website Bursa Efek Indonesia (BEI).

\section{Metode Pengumpulan Data}

Metode pengumpulan data yang digunakan adalah teknik dokumentasi.

\section{Operasional Variabel}

Pada penelitian ini, operasional variabel yang digunakan yaitu working capital to total asset, retained earning to total asset, earning before interest and tax to total asset, book value of equity to book value of total debt, earning before tax to current liabilities, sales to total asset, net income to total asset, total liabilities to total asset, current asset to current liabilities.

\section{Pengolahan dan Analisis Data}

Pengolahan dan analisis data pada penelitian ini menggunakan Microsoft Excel. Analisis data dalam penelitian ini melalui tahapan sebagai berikut:
1. Mengumpulkan data berupa laporan keuangan publikasi periode 2016 - 2019. Setelah data terkumpul, menghitung rasio prediksi kebangkrutan, lalu menghitung formula persamaan diskriminan dari setiap metode prediksi kebangkrutan yang digunakan dengan menggunakan Microsoft Excel;

2. Mengelompokkan hasil perhitungan prediksi kebangkrutan berdasarkan cut off setiap metode prediksi kebangkrutan;

3. Menghitung tingkat akurasi dari setiap metode prediksi kebangkrutan yang digunakan dengan mencocokkan hasil perhitungan prediksi kebangkrutan dengan kondisi keuangan yang sebenarnya, mengacu pada keadaan net income negative pada laporan keuangan perusahaan. Dalam penelitian ini, perusahaan yang masuk dalam kelompok grey area akan dikategorikan ke dalam perusahaan tidak bangkrut, karena menurut penelitian yang dilakukan oleh Suwitno (2013), 93\% perusahaan yang masuk dalam kategori grey area tidak mengalami kebangkrutan pada tahun-tahun berikutnya (Jayanti, Queeneria, dan Rustiana, 2015);

4. Menginterpretasikan hasil perhitungan dari setiap metode prediksi kebangkrutan, dan menentukan metode prediksi kebangkrutan manakah yang paling akurat untuk digunakan.

\section{HASIL DAN PEMBAHASAN}

Analisis Prediksi Metode Altman Modifikasi

Hasil perhitungan dari keempat rasio perusahaan jasa transportasi taksi konvensional akan dikalikan dengan standar dari masing-masing sesuai dengan ketentuan formula metode Altman Modifikasi, disajikan dalam tabel berikut:

Tabel 4.1

Hasil Analisis Metode Altman Modifikasi

\begin{tabular}{|c|c|c|c|c|c|c|c|}
\hline Kode & Tahun & $\mathbf{X}_{\mathbf{1}}$ & $\mathbf{X}_{\mathbf{2}}$ & $\mathbf{X}_{\mathbf{3}}$ & $\mathbf{X}_{\mathbf{4}}$ & $\begin{array}{c}\mathbf{Z}- \\
\text { Score }\end{array}$ & Kriteria \\
\hline \multirow{4}{*}{ BIRD } & 2016 & 0,009 & 0,247 & 0,111 & 1,768 & 3,467 & $\begin{array}{c}\text { Tidak } \\
\text { bangkrut }\end{array}$ \\
\cline { 2 - 8 } & 2017 & 0,051 & 0,316 & 0,087 & 3,110 & 5,220 & $\begin{array}{c}\text { Tidak } \\
\text { bangkrut }\end{array}$ \\
\cline { 2 - 8 } & 2018 & 0,066 & 0,343 & 0,080 & 3,115 & 5,359 & $\begin{array}{c}\text { Tidak } \\
\text { bangkrut }\end{array}$ \\
\cline { 2 - 8 } & 2019 & 0,025 & 0,336 & 0,050 & 2,682 & 4,413 & $\begin{array}{c}\text { Tidak } \\
\text { bangkrut }\end{array}$ \\
\hline \multirow{4}{*}{ TAXI } & 2016 & 0,210 & 0,077 & $-0,010$ & 0,405 & 1,987 & Grey area \\
\cline { 2 - 8 } & 2017 & $-0,041$ & $-0,145$ & $-0,190$ & 0,140 & $-1,874$ & Bangkrut \\
\cline { 2 - 8 } & 2018 & $-0,870$ & $-0,884$ & $-0,237$ & $-0,315$ & $-10,515$ & Bangkrut \\
\cline { 2 - 8 } & 2019 & $-1,067$ & $-2,903$ & $-0,549$ & $-0,486$ & $-20,660$ & Bangkrut \\
\hline
\end{tabular}

Sumber: Data diolah, 2020 
Berdasarkan tabel hasil analisis prediksi kebangkrutan PT Blue Bird Tbk. dengan metode Altman Modifikasi pada periode 2016 - 2019, menunjukkan bahwa nilai Z-Score mengalami kenaikan pada tahun 2017 - 2018 tetapi mengalami penurunan pada tahun 2019. Dimana nilai tertinggi Z-Score berada pada tahun 2018 dengan score 5,359 masuk dalam kriteria tidak bangkrut, dan nilai terendah Z-Score berada pada tahun 2016 dengan score 3,467 masuk dalam kriteria tidak bangkrut. Dalam perhitungan ini juga dapat dilihat bahwa pada periode 2016 - 2019, PT Blue Bird Tbk. tidak mengalami masalah kesulitan keuangan terutama pada rasio $X_{1}, X_{2}, X_{3}$ dan $X_{4}$

Sedangkan berdasarkan tabel hasil analisis prediksi kebangkrutan PT Express Transindo Utama Tbk. dengan metode Altman Modifikasi pada periode 2016 - 2019, menunjukkan bahwa nilai Z-Score mengalami penurunan dari tahun ke tahun. Dimana nilai tertinggi Z-Score berada pada tahun 2016 dengan score 1,987 masuk dalam kriteria grey area, dan nilai terendah Z-Score berada pada tahun 2019 dengan score -20,660 masuk dalam kriteria bangkrut. Dalam perhitungan ini juga dapat dilihat bahwa pada periode 2017 - 2019, PT Express Transindo Utama Tbk. mengalami masalah kesulitan keuangan, karena rasio $\mathrm{X}_{1}$ bernilai negatif yang artinya keseluruhan aset tidak mampu dalam menghasilkan modal kerja perusahaan, rasio $X_{2}$ bernilai negatif yang artinya keseluruhan aset perusahaan tidak mampu dalam menghasilkan laba ditahan perusahaan, rasio $\mathrm{X}_{3}$ bernilai negatif yang artinya keseluruhan aset perusahaan tidak mampu dalam menghasilkan laba sebelum bunga dan pajak perusahaan, dan rasio $X_{4}$ bernilai negatif yang artinya perusahaan tidak mampu dalam mengendalikan hutangnya.

\section{Analisis Prediksi Metode Springate}

Hasil perhitungan dari keempat rasio perusahaan jasa transportasi taksi konvensional akan dikalikan dengan standar dari masing-masing sesuai dengan ketentuan formula metode Springate disajikan dalam tabel berikut:

Tabel 4.2

Hasil Analisis Metode Springate

\begin{tabular}{|c|c|c|c|c|c|c|c|}
\hline Kode & Tahun & A & B & C & D & $\begin{array}{c}\text { S- } \\
\text { Score }\end{array}$ & Kriteria \\
\hline \multirow{3}{*}{ BIRD } & 2016 & 0,009 & 0,111 & 0,850 & 0,657 & 1,173 & $\begin{array}{c}\text { Tidak } \\
\text { bangkrut }\end{array}$ \\
\cline { 2 - 8 } & 2017 & 0,051 & 0,087 & 1,290 & 0,645 & 1,430 & $\begin{array}{c}\text { Tidak } \\
\text { bangkrut }\end{array}$ \\
\cline { 2 - 8 } & 2018 & 0,066 & 0,080 & 0,986 & 0,607 & 1,207 & $\begin{array}{c}\text { Tidak } \\
\text { bangkrut }\end{array}$ \\
\cline { 2 - 8 } & 2019 & 0,025 & 0,050 & 0,549 & 0,545 & 0,760 & Bangkrut \\
\hline
\end{tabular}

\begin{tabular}{|c|c|c|c|c|c|c|c|}
\hline Kode & Tahun & A & B & C & D & $\begin{array}{c}\text { S- } \\
\text { Score }\end{array}$ & Kriteria \\
\hline \multirow{4}{*}{ TAXI } & 2016 & 0,210 & $-0,010$ & $-1,278$ & 0,242 & $-0,562$ & Bangkrut \\
\cline { 2 - 8 } & 2017 & $-0,041$ & $-0,190$ & $-1,026$ & 0,152 & $-1,243$ & Bangkrut \\
\cline { 2 - 8 } & 2018 & $-0,870$ & $-0,237$ & $-0,544$ & 0,190 & $-1,907$ & Bangkrut \\
\cline { 2 - 8 } & 2019 & $-1,067$ & $-0,549$ & $-0,284$ & 0,280 & $-2,858$ & Bangkrut \\
\hline
\end{tabular}

Sumber: Data diolah, 2020

Berdasarkan tabel hasil analisis prediksi kebangkrutan PT Blue Bird Tbk. dengan metode Springate pada periode 2016 - 2019, menunjukkan bahwa nilai S-Score mengalami kenaikan pada tahun 2017 tetapi mengalami penurunan pada tahun 2018 2019, dimana nilai S-Score tertinggi berada pada tahun 2017 dengan score 1,430 masuk dalam kriteria tidak bangkrut, dan nilai terendah S-Score berada pada tahun 2019 dengan score 0,760 masuk dalam kriteria bangkrut. Dalam perhitungan ini juga dapat dilihat bahwa pada periode 2016 - 2019, PT Blue Bird Tbk. tidak mengalami masalah kesulitan keuangan terutama pada rasio $\mathrm{A}, \mathrm{B}, \mathrm{C}$, dan $\mathrm{D}$.

Sedangkan berdasarkan tabel hasil analisis prediksi kebangkrutan PT Express Transindo Utama Tbk. dengan metode Springate pada periode 2016 2019, menunjukkan bahwa nilai S-Score mengalami penurunan dari tahun ke tahun, dimana nilai tertinggi S-Score berada pada tahun 2016 dengan score - 0,562 masuk dalam kriteria bangkrut, dan nilai terendah SScore berada pada tahun 2019 dengan score -2,858 masuk dalam kriteria bangkrut. Dalam perhitungan ini juga dapat dilihat bahwa pada periode 2017-2019, PT Express Transindo Utama Tbk. mengalami masalah kesulitan keuangan karena rasio A bernilai negatif yang artinya keseluruhan aset tidak mampu dalam menghasilkan modal kerja perusahaan, rasio $B$ bernilai negatif yang artinya keseluruhan aset perusahaan tidak mampu dalam menghasilkan laba sebelum bunga dan pajak perusahaan, rasio $\mathrm{C}$ bernilai negatif yang artinya keseluruhan laba sebelum pajak perusahaan tidak mampu dalam memenuhi kewajiban lancar perusahaan.

\section{Analisis Prediksi Metode Grover}

Hasil perhitungan dari keempat rasio perusahaan jasa transportasi taksi konvensional akan dikalikan dengan standar dari masing-masing sesuai dengan ketentuan formula metode Springate disajikan dalam tabel berikut: 
Tabel 4.3

Hasil Analisis Metode Grover

\begin{tabular}{|c|c|c|c|c|c|c|}
\hline Kode & Tahun & $\mathbf{X}_{\mathbf{1}}$ & $\mathbf{X}_{\mathbf{2}}$ & $\mathbf{R O A}$ & $\begin{array}{c}\text { G- } \\
\text { Score }\end{array}$ & Kriteria \\
\hline \multirow{4}{*}{ BIRD } & 2016 & 0,009 & 0,111 & 0,070 & 0,450 & $\begin{array}{c}\text { Tidak } \\
\text { bangkrut }\end{array}$ \\
\cline { 2 - 7 } & 2017 & 0,051 & 0,087 & 0,066 & 0,439 & $\begin{array}{c}\text { Tidak } \\
\text { bangkrut }\end{array}$ \\
\cline { 2 - 7 } & 2018 & 0,066 & 0,080 & 0,066 & 0,440 & $\begin{array}{c}\text { Tidak } \\
\text { bangkrut }\end{array}$ \\
\cline { 2 - 7 } & 2019 & 0,025 & 0,050 & 0,043 & 0,269 & $\begin{array}{c}\text { Tidak } \\
\text { bangkrut }\end{array}$ \\
\hline \multirow{4}{*}{ TAXI } & 2016 & 0,210 & $-0,010$ & $-0,072$ & 0,368 & $\begin{array}{c}\text { Tidak } \\
\text { bangkrut }\end{array}$ \\
\cline { 2 - 7 } & 2017 & $-0,041$ & $-0,190$ & $-0,245$ & $-0,663$ & Bangkrut \\
\cline { 2 - 7 } & 2018 & $-0,870$ & $-0,237$ & $-0,659$ & $-2,196$ & Bangkrut \\
\cline { 2 - 7 } & 2019 & $-1,067$ & $-0,549$ & $-0,576$ & $-3,580$ & Bangkrut \\
\hline
\end{tabular}

Sumber: Data diolah, 2020

Berdasarkan tabel hasil analisis prediksi kebangkrutan PT Blue Bird Tbk. dengan metode Grover pada periode 2016 - 2019, menunjukkan bahwa nilai G-Score berfluktuasi setiap tahun, dimana nilai tertinggi G-Score berada pada tahun 2016 dengan score 0,450 masuk dalam kriteria tidak bangkrut, sedangkan nilai terendah G-Score berada pada tahun 2019 dengan score 0,269 masuk dalam kriteria tidak bangkrut. Dalam perhitungan ini juga dapat dilihat bahwa pada periode 2016 - 2019, PT Blue Bird Tbk. tidak mengalami masalah kesulitan keuangan terutama pada rasio $\mathrm{X}_{1}, \mathrm{X}_{2}$, dan ROA.

Sedangkan berdasarkan tabel hasil analisis prediksi kebangkrutan PT Express Transindo Utama Tbk. dengan metode Grover pada periode 2016 - 2019, menunjukkan bahwa nilai G-Score mengalami penurunan dari tahun ke tahun, dimana nilai tertinggi G-Score berada pada tahun 2016 dengan score 0,368 masuk dalam kriteria tidak bangkrut, dan nilai terendah G-Score berada pada tahun 2019 dengan score -3,580 masuk dalam kriteria bangkrut. Dalam perhitungan ini juga dapat dilihat bahwa pada periode 2017-2019, PT Express Transindo Utama Tbk. mengalami masalah kesulitan keuangan, karena rasio $\mathrm{X}_{1}$ bernilai negatif yang artinya keseluruhan aset tidak mampu dalam menghasilkan modal kerja perusahaan, rasio $\mathrm{X}_{2}$ bernilai negatif yang artinya keseluruhan aset perusahaan tidak mampu dalam menghasilkan laba sebelum bunga dan pajak perusahaan, dan rasio ROA bernilai negatif yang artinya keseluruhan aset perusahaan tidak mampu dalam menghasilkan laba bersih perusahaan atau tingkat profitabilitas sangat rendah. Semakin tinggi pertumbuhan laba perusahaan, maka tingkat profitabilitas juga akan semakin meningkat, begitupun sebaliknya. (Wijayanti, Mawardi, Jasman, Halim, 2020).

\section{Analisis Prediksi Metode Zmijewski}

Hasil perhitungan dari keempat rasio perusahaan jasa transportasi taksi konvensional akan dikalikan dengan standar dari masing-masing sesuai dengan ketentuan formula metode Springate disajikan dalam tabel berikut:

Tabel 4.4

Hasil Analisis Metode Zmijewski

\begin{tabular}{|c|c|c|c|c|c|c|}
\hline Kode & Tahun & $\mathbf{X}_{\mathbf{1}}$ & $\mathbf{X}_{\mathbf{2}}$ & $\mathbf{X}_{\mathbf{3}}$ & $\begin{array}{c}\mathbf{X}- \\
\text { Score }\end{array}$ & Kriteria \\
\hline \multirow{4}{*}{ BIRD } & 2016 & 0,070 & 0,361 & 1,084 & $-2,551$ & $\begin{array}{c}\text { Tidak } \\
\text { bangkrut }\end{array}$ \\
\cline { 2 - 7 } & 2017 & 0,066 & 0,243 & 1,769 & $-3,201$ & $\begin{array}{c}\text { Tidak } \\
\text { bangkrut }\end{array}$ \\
\cline { 2 - 7 } & 2018 & 0,066 & 0,243 & 1,743 & $-3,206$ & $\begin{array}{c}\text { Tidak } \\
\text { bangkrut }\end{array}$ \\
\cline { 2 - 7 } & 2019 & 0,043 & 0,272 & 1,246 & $-2,938$ & $\begin{array}{c}\text { Tidak } \\
\text { bangkrut }\end{array}$ \\
\hline \multirow{4}{*}{ TAXI } & 2016 & $-0,072$ & 0,712 & 4,077 & 0,099 & Bangkrut \\
\cline { 2 - 7 } & 2017 & $-0,245$ & 0,877 & 0,846 & 1,806 & Bangkrut \\
\cline { 2 - 7 } & 2018 & $-0,659$ & 1,461 & 0,311 & 6,994 & Bangkrut \\
\cline { 2 - 7 } & 2019 & $-0,576$ & 1,947 & 0,291 & 9,394 & Bangkrut \\
\hline
\end{tabular}

Sumber: Data diolah, 2020

Berdasarkan tabel hasil analisis prediksi kebangkrutan PT Blue Bird Tbk. dengan metode Zmijewski pada periode 2016 - 2019, menunjukkan bahwa nilai X-Score mengalami kenaikan pada tahun 2017 - 2018 tetapi mengalami penurunan pada tahun 2019, dimana nilai tertinggi X-Score berada pada tahun 2018 dengan score -3,206 masuk dalam kriteria tidak bangkrut, dan nilai terendah X-Score berada pada tahun 2016 dengan score -2,551 masuk dalam kriteria tidak bangkrut. Dalam perhitungan ini juga dapat dilihat bahwa pada periode 2016 - 2019, PT Blue Bird Tbk. tidak mengalami masalah kesulitan keuangan terutama pada rasio $\mathrm{X}_{1}, \mathrm{X}_{2}$, dan $\mathrm{X}_{3}$, dan dapat dilihat juga pada rasio $X_{2}$ bahwa sebagian besar aset perusahaan dibiayai oleh ekuitas perusahaan karena memiliki score dibawah 0,5.

Sedangkan berdasarkan tabel hasil analisis prediksi kebangkrutan PT Express Transindo Utama Tbk. dengan metode Zmijewski pada periode 2016 2019, menunjukkan bahwa nilai X-Score mengalami penurunan dari tahun ke tahun, dimana nilai tertinggi X-Score berada pada tahun 2019 dengan score 0,099 masuk dalam kriteria bangkrut, dan nilai terendah XScore berada pada tahun 9,394 masuk dalam kriteria bangkrut. Dalam perhitungan ini juga dapat dilihat 
bahwa pada periode 2017 - 2019, PT Blue Bird Tbk. mengalami masalah kesulitan keuangan karena score rasio $X_{1}$ bernilai negatif yang artinya keseluruhan aset perusahaan tidak mampu dalam menghasilkan laba bersih perusahaan, dapat dilihat pada rasio $\mathrm{X}_{2}$ bahwa sebagian besar aset perusahaan dibiayai oleh kewajiban perusahaan karena memiliki score diatas 0,5 , dan dapat dilihat pada rasio $X_{3}$ bahwa perusahaan kurang mampu mempergunakan aset lancar dan kewajiban lancarnya dengan efisien karena pada tahun 2016 score diatas 2, dan kemungkinan perusahaan berada dalam kesulitan keuangan untuk memenuhi kewajiban lancarnya karena pada tahun 2017 - 2019 score $X_{3}$ dibawah 1.

\section{Analisis Tingkat Akurasi}

Hasil perhitungan tingkat akurasi dari keempat metode prediksi disajikan dalam tabel berikut:

Tabel 4.5

Hasil Analisis Tingkat Akurasi

\begin{tabular}{|c|c|c|c|c|}
\hline \multirow{2}{*}{ Tahun } & \multicolumn{2}{|c|}{ Altman Modifikasi } & \multicolumn{2}{c|}{ Springate } \\
\cline { 2 - 5 } & $\begin{array}{c}\text { Prediksi } \\
\text { Benar }\end{array}$ & Sampel & $\begin{array}{c}\text { Prediksi } \\
\text { Benar }\end{array}$ & Sampel \\
\hline 2016 & 1 & 2 & 2 & 2 \\
\hline 2017 & 2 & 2 & 2 & 2 \\
\hline 2018 & 2 & 2 & 2 & 2 \\
\hline 2019 & 2 & 2 & 1 & 2 \\
\hline Jumlah & $\mathbf{7}$ & $\mathbf{8}$ & $\mathbf{7}$ & $\mathbf{8}$ \\
\hline $\begin{array}{c}\text { Tingkat } \\
\text { Akurasi }\end{array}$ & & $\mathbf{8 8 \%}$ & & $\mathbf{8 8 \%}$ \\
\hline
\end{tabular}

Sumber: Data diolah, 2020

Tabel 4.6 (Lanjutan)

\begin{tabular}{|c|c|c|c|c|}
\hline \multirow{2}{*}{ Tahun } & \multicolumn{2}{|c|}{ Grover } & \multicolumn{2}{c|}{ Zmijewski } \\
\cline { 2 - 5 } & $\begin{array}{c}\text { Prediksi } \\
\text { Benar }\end{array}$ & Sampel & $\begin{array}{c}\text { Prediksi } \\
\text { Benar }\end{array}$ & Sampel \\
\hline 2016 & 1 & 2 & 2 & 2 \\
\hline 2017 & 2 & 2 & 2 & 2 \\
\hline 2018 & 2 & 2 & 2 & 2 \\
\hline 2019 & 2 & 2 & 2 & 2 \\
\hline Jumlah & $\mathbf{7}$ & $\mathbf{8}$ & $\mathbf{8}$ & $\mathbf{8}$ \\
\hline $\begin{array}{l}\text { Tingkat } \\
\text { Akurasi }\end{array}$ & & $\mathbf{8 8 \%}$ & & $\mathbf{1 0 0 \%}$ \\
\hline
\end{tabular}

Sumber: Data diolah, 2020

Berdasarkan tabel perhitungan tingkat akurasi, diketahui dari keempat metode analisis kebangkrutan yang digunakan dalam penelitian ini yaitu metode
Altman Modifikasi, Springate, Grover, dan Zmijewski, bahwa metode Zmijewski memiliki tingkat akurasi yang paling tinggi dengan nilai akurasinya $100 \%$ dalam memprediksi kebangkrutan 2 perusahaan jasa transportasi taksi konvensional periode 2016 - 2019, dikarenakan hasil prediksi kebangkrutan sesuai dengan kondisi keuangan yang sebenarnya dilihat dari laba bersih real yang dihasilkan perusahaan. Hal ini sejalan dengan penelitian yang dilakukan oleh Gunawan, Pamungkas, dan Susilawati (2017) menyimpulkan bahwa metode Zmijewski adalah metode yang memiliki tingkat akurasi yang paling tinggi untuk digunakan dalam memprediksi kebangkrutan perusahaan.

\section{SIMPULAN DAN SARAN}

Berdasarkan hasil analisis dan pembahasan, dapat disimpulkan sebagai berikut:

a. Berdasarkan analisis dengan metode Altman ZScore Modifikasi pada 2 perusahaan jasa transportasi taksi konvensional yang terdaftar di Bursa Efek Indonesia (BEI) pada periode 2016 - 2019, PT Blue Bird Tbk. berada dalam kriteria tidak bangkrut selama empat tahun berturut-turut, sedangkan PT Express Transindo Utama Tbk. berada dalam kriteria grey area pada tahun 2016 dan mengalami penurunan pada tahun 2017 - 2019 berada dalam kriteria bangkrut.

b. Berdasarkan analisis dengan metode Springate, PT Blue Bird Tbk. berada dalam kriteria tidak bangkrut pada tahun 2016 - 2018 dan mengalami penurunan pada tahun 2019 berada dalam kriteria bangkrut, sedangkan PT Express Transindo Utama Tbk. berada dalam kriteria bangkrut selama empat tahun berturut-turut.

Berdasarkan analisis dengan metode Grover, PT Blue Bird Tbk. berada dalam kriteria tidak bangkrut selama empat tahun berturut-turut, sedangkan PT Express Transindo Utama Tbk. berada dalam kriteria tidak bangkrut pada tahun 2016 dan mengalami penurunan pada tahun 2017 - 2019 berada dalam kriteria bangkrut.

a. Berdasarkan analisis dengan metode Zmijewski, PT Blue Bird Tbk. berada dalam kriteria tidak bangkrut selama empat tahun berturut-turut, sedangkan PT Express Transindo Utama Tbk. berada dalam kriteria bangkrut selama empat tahun berturut-turut.

b. Dari keempat metode yang digunakan dalam analisis prediksi kebangkrutan 2 perusahaan jasa transportasi taksi konvensional, yang memiliki 
tingkat akurasi yang paling tinggi adalah metode

Zmijewski dengan nilai akurasi 100\%.

Berdasarkan kesimpulan diatas, adapun saran yang dapat diberikan sebagai berikut:

a. Saran bagi perusahaan yang berada dalam kriteria grey area dan bangkrut, pihak manajemen perusahaan diharapkan dapat lebih memperhatikan kondisi keuangan perusahaan di setiap periode, terutama saat perusahaan dalam kriteria bangkrut, maka pihak manajemen perusahaan diharapkan melakukan tindakan evaluasi dan dapat mengambil langkah yang tepat untuk meningkatkan kondisi keuangan perusahaan.

b. Saran bagi perusahaan yang berada dalam kriteria tidak bangkrut, pihak manajemen perusahaan diharapkan dapat menjaga dan meningkatkan kondisi keuangan perusahaan agar tetap berada pada kriteria tidak bangkrut.

c. Saran bagi peneliti selanjutnya diharapkan untuk melakukan penelitian pada laporan keuangan tahun yang terbaru yaitu tahun 2020 dan seterusnya, atau dapat memperluas objek penelitian, dan memperluas penggunaan metode prediksi kebangkrutan perusahaan yang lain.

d. Saran bagi para investor sebelum memutuskan untuk melakukan investasi di suatu perusahaan, diharapkan dapat memperhatikan kondisi keuangan perusahaan dengan melakukan analisis kebangkrutan perusahaan salah satunya dapat menggunakan metode Zmijewski yang memiliki tingkat akurasi yang paling tinggi untuk memprediksi kebangkrutan 2 perusahaan jasa transportasi taksi konvensional.

\section{DAFTAR PUSTAKA}

Effendi, R. (2018). Analisis prediksi kebangkrutan dengan menggunakan metode Altman, Springate, Zmijewski, Foster, dan Grover pada emiten jasa transportasi. Parsimonia Jurnal Akuntansi, Manajemen, dan Bisnis, 4(3), 307318. Universitas Ma Chung Malang.

Gunawan, B., Pamungkas, R., dan Susilawati, D. (2017). Perbandingan Prediksi Financial Distress dengan Model Altman, Grover, dan Zmijewski. Jurnal Akuntansi dan Investasi, 18(1), 119-127. Universitas Muhammadiyah Yogyakarta.
Jayanti, Queenaria, dan Rustiana. (2015). Analisis Tingkat Akurasi Model-Model Prediksi Kebangkrutan Untuk Memprediksi Voluntary Auditor Switching (Studi Pada Perusahaan Manufaktur Yang Terdaftar di BEI). Jurnal Modus, 27(2), 87-108. Universitas Atma Jaya Yogyakarta.

Nugroho, S., A. (2018). Hukum Kepailitan di Indonesia Dalam Teori dan Praktik beserta Penerapan Hukumnya. Jakarta: Prenadamedia Group. Pertapan, M. F. A.,

Hartono, S., dan Wulan, I. A. D. P. (2018). Bankruptcy Prediction in PT Blue Bird, Tbk 2011-2016 Using Altman Z- Score, Springate, and Zmijewski Model. International Conference on Technology, Education, and Social Science 2018 (The $2^{\text {nd }}$ ICTESS 2018), 203-212.

Prasetyo, L. F., Noor, R., dan Amiruddin. (2018). Analisis prediksi financial distress pada perusahaan transportasi darat dan terdaftar di BEI pelaporan 2012-2017. Jurnal Akuntansi Multi Dimensi (JAMDI), 4(1), 47-53. Politeknik Negeri Samarinda.

Suryana, A. (2019). Analysis of Stock Prices: A Case Study of Indonesian Stock Exchange. International Journal of Innovation, Creativity and Change, 6(11), 327-334. Universitas Widyatama.

Wijayanti, I., Mawardi, R., Jasman, Halim, A. B. (2020). The Effect of Corporate Social Responsibility Disclosure, Leverage, Firm Size, and Profitability Toward Earnings Response Coefficient. International Journal of Innovation, Creativity and Change, 13(3), 1202-1216. Perbanas Institute.

www.idx.co.id 
